Review article

\title{
Considerations in the study of tree fine-root turnover with minirhizotrons
}

\author{
Takami Satomura $^{1 *}$, Karibu Fukuzawa $^{2}$ and Takao Horikoshi ${ }^{3}$ \\ ${ }^{1}$ Graduate School of Biosphere Science, Hiroshima University, 1-7-1, Kagamiyama, Higashi-Hiroshima 729-8521, \\ Japan. \\ ${ }^{2}$ Graduate School of Agriculture, Hokkaido University, 250 Tokuda, Nayoro 096-0071, Japan. \\ ${ }^{3}$ Graduate School of Integrated Arts and Sciences, Hiroshima University, 1-7-1, Kagamiyama, Higashi-Hiroshima \\ 729-8521, Japan. \\ * Present address: Field Science Center for Northern Biosphere, Hokkaido University, N9 W9, Sapporo 060-0809, \\ Japan. \\ Corresponding author: T. Satomura, E-mail: takami_satomura@ybb.ne.jp, Phone: +81-11-706-3653, Fax: \\ $+81-11-706-3450$
}

Received on Octorber 7, 2006; Accepted on April 10, 2007

\begin{abstract}
Fine-root turnover is an important component of forest carbon dynamics. We detail the characteristics of the minirhizotron method of measuring fine-root turnover and discuss its methodological implications. Minirhizotron data are relative values proportional to the data taken from the bulk, in situ soil, since they are taken at the soil-tube interface, so we propose several ways to validate minirhizotron data. Most short-term studies show fine-root production to be higher than fine-root mortality, suggesting that disturbance resulting from minirhizotron installation continues for several years. Initial-years results tend to lead to overestimates of fine-root dynamics, although these results define the maximal limits of fine-root production and mortality. We compare the definitions of fine-root turnover and methods of calculation used in different studies. We find that values of fine-root turnover depend on the definition of fine roots, methods of measurement, definition of turnover, and methods of calculation, so these factors must be taken into account when turnover values are discussed. In addition, soil depth is a key factor in the study of fine-root turnover, as is variation in the physical qualities, form and function, of the fine roots. Further long-term research into these key factors in relation to biotic and abiotic parameters will improve our knowledge of forest carbon dynamics.
\end{abstract}

Key words: decomposition, fine root demography, forest carbon cycling, mortality, production, longevity
Abbreviations: NPP, net primary production; PDD cycle, production-death-decomposition cycle

\section{Introduction}

In studies of forest ecosystems, tree root systems are frequently categorized into fine roots and coarse roots. Fine roots are defined as those roots with the finest diameter (generally $\leq 1-2 \mathrm{~mm}$ ). The maximal limit of the "fine" root class is arbitrarily defined depending on the site and target plants (see the reviews of Vogt et al., 1996 and Gill and Jackson, 2000). Since they have a faster respiration rate (Pregitzer et al., 1998), a faster turnover rate (Gholz et al., 1986), and potentially more active water and nutrient acquisition than larger roots (Eissenstat, 1992), fine roots have key roles in plant nutrition, water acquisition, and ecosystem carbon dynamics. Although the live fine-root standing biomass only accounts for between $1 \%$ and $12 \%$ of total forest tree biomass, between $10 \%$ and $60 \%$ of net primary production (NPP) of trees in forests is consumed in the production-death-decomposition cycle (PDD cycle) of fine roots, otherwise known as root turnover (Keyes and Grier, 1981; Vogt et al., 1982; Comeau and Kimmins, 1989; Janssens et al., 2002). Therefore, the carbon turnover associated with the PDD cycle of fine roots is an important component of forest carbon cycling, and an accurate estimation of fine-root turnover is needed to better explain forest carbon dynamics.

Generally, the rate of fine-root turnover is defined as the proportion of fine-root production to standing fine-root abundance (on a weight-basis, length-basis, etc.). Fine-root turnover has been studied using

Satomura T, Fukuzawa K and Horikoshi T 2007 Considerations in the study of tree fine-root turnover with minirhizotrons. Plant Root 1: 34-45. doi:10.3117/plantroot.1.34

Copyrights 2007, Plant Root (JSRR), 
several direct methods such as the sequential soil core sampling method, in-growth core sampling method and minirhizotron method, and indirect methods such as the carbon budget method, nitrogen budget method and carbon isotope method (Gill and Jackson, 2000; Majdi et al., 2005). Traditionally, values obtained from the sequential soil coring method or the in-growth core method have been preferred for the study of fine-root dynamics and for the calculation of fine-root turnover (Vogt et al., 1998; Fahey et al., 1999). These destructive methods have the advantages that dead fine roots can be recognized and fine-root dry-mass production per unit soil volume can be estimated. However, these methods cannot be used to estimate the amount of fine roots that die and decompose over a period, and therefore the net fine-root mortality. It is possible to underestimate the amount of dead fine roots and to both under- and overestimate that of the produced fine roots (Kurz and Kimmins, 1987; Publicover and Vogt, 1993). Finally, destructive methods cause repeated and prolonged soil disturbance, so are not suitable for long-term research.

One of the direct methods used to study fine roots, the minirhizotron method, has become popular in the study of fine-root dynamics and demography. This non-destructive method generally provides more accurate estimates of fine-root turnover than do other, traditional, destructive methods (Hendricks et al., 2006), and the collection of data by this method has increased markedly recently. In this article, we focus on the minirhizotron method for the study of fine root turnover and detail its characteristics and methodological considerations with data validation procedures. In the minirhizotron method, there are several models and calculations used to clarify the definitions of fine-root turnover, which can lead to differing turnover estimates (e.g. Hynes and Gower, 1995; Tierney and Fahey, 2002; West et al., 2004), which this study focuses on in detail. Moreover, we discuss the variation of fine-root turnover estimates with respect to variation of fine-root qualities within $\leq 2 \mathrm{~mm}$ fine roots (see Trumbore and Gaudinski, 2003; Guo et al., 2004), as well as soil abiotic/biotic conditions at different soil depths (see Aerts et al., 1989; Milchunas et al., 2005).

\section{The minirhizotron method of fine-root study}

The minirhizotron method is a non-destructive method in which transparent tubes are installed in the study field, and fine roots on the soil-tube boundary are recorded using a CCD (charge-coupled device) camera (Fahey et al., 1999; Smit et al., 2000; Johnson et al., 2001; Satomura et al., 2001). The minirhizotron method has been used for long-term root dynamics research since the late 1980s (Taylor, 1987; Majdi, 1996; Johnson et al., 2001; Satomura et al., 2001).
Installation of the observation tubes causes a brief soil disturbance, but then permits direct observation of fine roots through a transparent interface and enables evaluation of the spatial distribution pattern of fine roots and root demography by continual observation of the individual rootlets (Majdi, 1996; Smit et al., 2000). This ability to observe individual rootlets directly and continuously is why many researchers prefer this method, and for these reasons the minirhizotron method is considered to be suitable for long-term research (Smit et al., 2000).

The minirhizotron method has many advantages, but also some disadvantages. On the positive side, we can observe fine roots at the soil-tube interface and evaluate root abundance in terms of two-dimensional data, such as root length, root projected area, or root surface area per unit of observation area. In addition to net fine-root production, net fine-root mortality (or disappearance; see below for related material) can also be measured as two-dimensional data. These net values cannot be directly obtained when using the destructive methods. In other words, using this method we can evaluate the quantity of fine-root litter put into soil as soil organic matter, as well as how much NPP is consumed for fine-root production. Evaluation of these parameters is very informative for a better understanding of soil carbon dynamics.

However, using this method we cannot observe the fine roots in bulk soil (in situ), and therefore the fine-root abundance is a relative value (Majdi, 1996; Smit et al., 2000). Accordingly, when we estimate the stand-level fine-root standing biomass and production using the minirhizotron method, we have to convert two-dimensional data into three-dimensional values such as root dry weight per unit soil volume or per unit ground surface area. Fortunately, many studies have found correlations between minirhizotron data and soil core sample data (e.g. Thomas et al., 1996; Hendrick and Pregitzer, 1996; Ephrath et al., 1999; Satomura et al., 2006).

To obtain the stand-level fine-root production (dry-weight-based fine-root production per unit ground area) from minirhizotrons, there are several conversion approaches. Root-length-based fine-root production data collected by the minirhizotron method is sometimes converted into dry-weight-based production data per unit soil volume directly, without the calculation of turnover value (Noguchi et al., 2004; 2005). In another approach, dry-weight-based fine-root production per unit soil volume is estimated by the combination of two methods under the assumption that the product of the fine-root standing biomass and its turnover per year gives the annual fine-root production (e.g., Gill et al., 2002; Satomura, 2003; Fukuzawa et al., 2007); in this approach, fine-root standing biomass (dry-weight basis) per unit 
soil volume is derived by soil core sampling, and fine-root turnover is calculated from minirhizotron data on a fine-root length basis. The sum of the dry-weight-based fine-root production per unit soil volume at all soil depths gives the stand-level fine-root production (i.e., the dry-weight-based fine-root production per unit ground surface). Using a combination of the soil core sampling method and the minirhizotron method for the estimation of stand-level fine-root production provides the advantages of both methods and compensates for their disadvantages.

\section{Definitions of fine-root turnover estimated with minirhizotrons}

In the minirhizotron methods, the term 'root turnover' has various definitions associated with the dynamic processes of root production, death, and decomposition (Tingey et al., 2000). There are two dry-matter transfer compartment models, each depending on the combinations of dry matter compartments and dry matter transfer processes: the live fine-root abundance-based model (Fig. 1a) and the visible fine-root (live and dead) abundance-based model (Fig. 1b). The latter model is used when live and dead roots are not distinguishable (tactile cues, such as brittleness, are not available in image analysis). These models incorporate three types of dry matter transfer processes. The first is based on fine-root production ('production'; processes i and iv). The second is based on fine-root death ('mortality'; process ii). The third is based on fine-root decomposition, throughput, detritus input, herbivory and so on (processes iii and v) (for terminology see Stanton, 1988; Tingey et al., 2000). We use the term 'disappearance' to denote the phenomena of the third type, all of which were observed in the minirhizotron study. Fine-root turnover can be directly calculated from the two-dimensional data obtained by the minirhizotron method without the conversion of the data into dry-mass-based data, by using equations (1) to (14) in Table 1 (e.g., Gill et al., 2002; Satomura et al., 2006).

Using the minirhizotron method, it is usually difficult to distinguish dead roots from live roots, favoring adoption of the visible fine-root model (Fig. 1b) (e.g. Ponti et al., 2004; West et al., 2004; Satomura et al., 2006). Despite this difficulty, we can estimate net dry-matter transfer in process iv (Fig. 1b) from the amount of visible and produced roots, and turnover values can be calculated using equations (7) to (9) in Table 1 (e.g., Milchunas et al., 2005; Satomura et al., 2006; Fukuzawa et al. in press). In addition, net dry-matter transfer in process $\mathrm{v}$ (Fig. 1b) can be estimated from the quantities of visible and disappeared roots, and turnover values can be calculated using equations (10) to (12) in Table 1. Many re- a) Live fine-root model b) Visible fine-root model

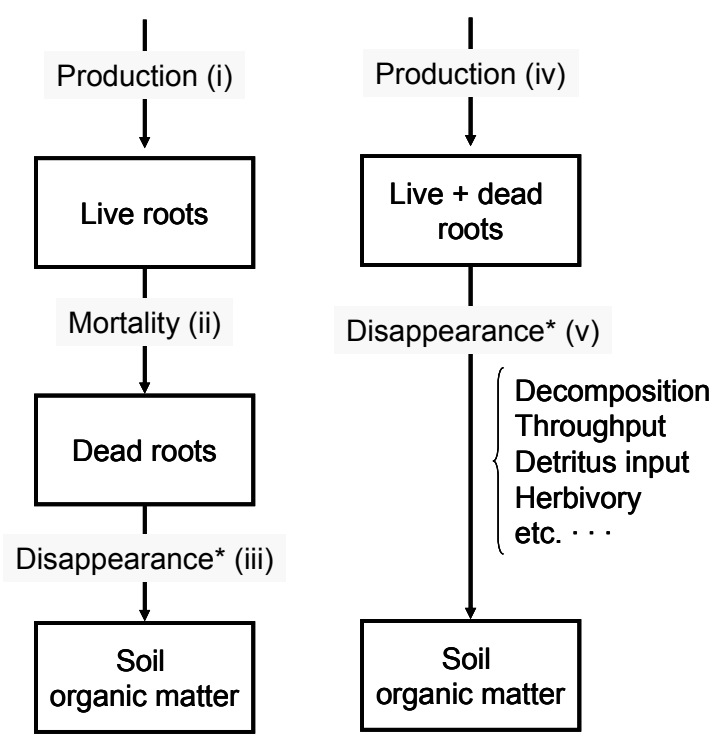

Fig. 1. Two types of dry-matter transfer compartment models, with root compartments and processes of dry matter transfer among them. (a) Based on live fine-root abundance. (b) Based on visible fine-root (live + dead) abundance. Each arrow represents a transfer process: $i$ and iv, production; ii, mortality; iii and $\mathrm{v}$, decomposition, throughput, detritus input, or herbivory $\left({ }^{*}\right.$ we use the term 'disappearance' to represent these several phenomena in processes iii and v). These processes have different connotations for fine-root turnover. Fine-root turnover is variously defined depending on the dry matter transfer processes and the combinations of root dry-matter compartments. Division of net dry matter transfer as the numerator by live fine-root abundance or visible fine-root abundance as the denominator gives fine-root turnover (Table 1. Equations (1) to (12)). Modified from Tingey et al. (2000).

searchers have tried to distinguish dead roots from live roots by color (e.g. Aerts et al., 1989; Hendrick and Pregitzer, 1992; Joslin et al., 2000) or shrinkage (Tierney et al., 2003). The sum of dark roots (or shrunken roots) and disappeared roots is regarded as the quantity of dead roots. These data are used in the live fine-root model (Fig. 1a). In this case, we can estimate net dry-matter transfer in process i (Fig. 1a) from the quantity of live and produced roots, and turnover values can be calculated using equations (1) to (3) in Table 1 (e.g., Burton et al., 2000; Gill et al., 2002). Net dry-matter transfer in process ii (Fig. 1a) can also be estimated from the quantity of live, visible dead, and disappeared roots, and turnover values can be calculated using equations (4) to (6) in Table 1. Note that the transfers in processes ii (Fig. 1a) and $v$ (Fig. 1b) are sometimes termed 'mortality' in the literature. We use this term only for process ii (Fig. 1a), and use the term 'disappearance' for process v (Fig. 1b) to maintain consistency with the abovementioned concepts. Where we could not find a definition of dead roots in the literature, we used the visible fine-root 
Table 1. Various definitions of fine-root turnover* $\left(\right.$ year $\left.^{-1}\right)$ from minirhizotron data. There are two types of dry matter transfer models: based on live fine-root abundance (Fig. 1a) and on visible fine-root (live + dead) abundance (equations (1) to (12)). The other turnover concept is based on the median fine-root life span (equation (13)) and the regression model (equation (14)), respectively. Turnover under the process (iii) in Fig.1 are not shown, since root researchers generally do not take it into consideration.

\begin{tabular}{|c|c|c|c|}
\hline Base & Denomination & Equation & $\begin{array}{l}\text { Example value } \\
\text { in a stand }\end{array}$ \\
\hline \multirow[t]{6}{*}{$\begin{array}{l}\text { Live fine-root } \\
\text { (Fig.1a) }\end{array}$} & \multirow[t]{3}{*}{$\begin{array}{l}\text { Production turnover } \\
\text { under process (i) }\end{array}$} & $\begin{array}{l}\text { (1) net fine-root production / mean live fine-root abun- } \\
\text { dance }\end{array}$ & - \\
\hline & & $\begin{array}{l}\text { (2) net fine-root production / minimum live fine-root } \\
\text { abundance }\end{array}$ & - \\
\hline & & $\begin{array}{l}\text { (3) net fine-root production / maximum live fine-root } \\
\text { abundance }\end{array}$ & - \\
\hline & \multirow[t]{3}{*}{$\begin{array}{l}\text { Mortality turnover } \\
\text { under process (ii) }\end{array}$} & $\begin{array}{l}\text { (4) net fine-root mortality / mean live fine-root abun- } \\
\text { dance }\end{array}$ & - \\
\hline & & $\begin{array}{l}\text { (5) net fine-root mortality / minimum live fine-root } \\
\text { abundance }\end{array}$ & - \\
\hline & & $\begin{array}{l}\text { (6) net fine-root mortality / maximum live fine-root } \\
\text { abundance }\end{array}$ & - \\
\hline \multirow{6}{*}{$\begin{array}{l}\text { Visible (live+dead) } \\
\text { fine-root } \\
\quad \text { (Fig.1b) }\end{array}$} & \multirow[t]{3}{*}{$\begin{array}{l}\text { Production turnover } \\
\text { under process (iv) }\end{array}$} & $\begin{array}{l}\text { (7) net fine-root production / mean visible fine-root } \\
\text { abundance }\end{array}$ & 2.4 \\
\hline & & $\begin{array}{l}\text { (8) net fine-root production / minimum visible fine-root } \\
\text { abundance }\end{array}$ & 5.6 \\
\hline & & $\begin{array}{l}\text { (9) net fine-root production / maximum visible fine-root } \\
\text { abundance }\end{array}$ & 1.7 \\
\hline & \multirow[t]{3}{*}{$\begin{array}{l}\text { Disappearance turnover } \\
\text { under process }(\mathrm{v})\end{array}$} & $\begin{array}{l}\text { (10) net fine-root disappearance / mean visible fine-root } \\
\text { abundance }\end{array}$ & 1.5 \\
\hline & & $\begin{array}{l}\text { (11) net fine-root disappearance / minimum visible } \\
\text { fine-root abundance }\end{array}$ & 3.7 \\
\hline & & $\begin{array}{l}\text { (12) net fine-root disappearance / maximum visible } \\
\text { fine-root abundance }\end{array}$ & 1.0 \\
\hline Life span & Turnover & (13) $1 /$ median fine-root life span & $\begin{array}{l}5.2^{\mathrm{a}}, 1.4^{\mathrm{b}} \\
1.9^{\mathrm{c}}, 2.0^{\mathrm{d}}\end{array}$ \\
\hline Regression & Turnover & $\begin{array}{l}\text { (14) Obtain the regression between the fine-root produc- } \\
\text { tion to disappearance ratio in each observation period } \\
(Y) \text { against the time after tube installation }(X) \text {. Re- } \\
\text { garded the } X \text {-intercept at } Y=1 \text { as the turnover time } \\
\text { (inverse of turnover). }\end{array}$ & - \\
\hline
\end{tabular}

*Yearly total values of net fine-root production, net fine-root mortality and net fine-root disappearance are used in the equations (1) to (12). Median fine-root life span (year) and turnover time (year) are used in the equations (13) and (14), respectively. "Data taken at soil surface (0-15 cm in depth from ground surface) in a cool-temperate, deciduous forest in the Teshio Experimental Forest in northern Japan (some of the data are shown in Fukuzawa 2007 and Fukuzawa et al. 2007, and the others are unpublished). Turnover values based on median life span differ among roots produced in May (a), June (b), July (c), and August (d) 2002. Our data are based on the visible fine-root model, and our inability to discriminate dead roots from live roots prevents us from obtaining the turnover values in the live fine-root model. Turnover based on the regression model is also not calculated.

abundance-based model (Fig. 1b). In the discussion of fine-root turnover, root researchers generally do not take the turnover in process iii (Fig. 1a) into consideration.

Even when the amounts of net dry matter transfer are the same, the calculated production turnover values differ depending on the model used and the methods used to calculate fine-root turnover. For example, processes $\mathrm{i}$ and iv are concerned with fine-root production; the denominator is live fine-root abundance in the former and visible fine-root (live and dead) abundance in the latter. Researchers can use mean, maximum, or minimum live fine-root abundance as denominators in processes i and ii (Fig. 1a; Table 1), and mean, maximum, or minimum visible fine-root (live and dead) abundance in processes iv and v (Fig. 1b). Thus, even when the amounts of net fine-root production are the same, we can obtain six 
production turnover values using equations (1) to (3) and (7) to (9) (Table 1). Similarly, fine-root mortality in process ii gives three turnover values using equations (4) to (6), and fine-root disappearance in process $\mathrm{v}$ gives three turnover values using equations (10) to (12) (Table 1).

In another approach, the inverse of the median lifespan of the fine-root cohort is used as the fine-root turnover rate (e.g., Burton et al., 2000; Tierney and Fahey, 2001; equation (13) in Table 1). Table 1 shows examples of the turnover values in a stand calculated from the various equations. The values obviously differ among the equations, varying 5.6-fold across the methods of calculation, from 1.0 using equation (12) to 5.6 using equation (8). Recently, Milchunas et al. (2005) proposed a new approach for the estimation of fine-root turnover. They regressed the ratio of fine-root production to disappearance in each observation period $(Y)$ against the time after tube installation $(X)$, and then proposed the $X$-intercept at $Y$ $=1$ as the turnover time (inverse of turnover). This approach gave a different turnover estimate to that obtained from the other approaches (Milchunas et al., 2005).

To summarize, in minirhizotron studies, different calculation methods lead to significantly varying estimates of fine-root turnover (Burton et al., 2000; West et al., 2004; Milchunas et al., 2005; Table 1). Consequently, we must pay attention to the calculation method when we compare data reported in the literature.

\section{Equilibration of fine-root dynamics at the soil-tube interface after disturbance by tube installation}

Many studies reported a fine-root production rate higher than the mortality rate (or disappearance rate) (e.g. Hendrick and Pregitzer, 1993; Noguchi et al., 2005; Satomura et al., 2006; Fukuzawa et al., 2007). If we put these data into the equations to calculate the turnover in processes $\mathrm{i}$ and ii (or iv and v), production turnover was higher than mortality turnover (or disappearance turnover) in each study. Table 2 shows a few studies that clarified the turnover values estimated from the concepts in Fig. 1 with calculations (1) to (12) in Table 1. It is likely that the differences are attributable mainly to the short-term disturbances caused by tube installation, and partly to the short-term observation period, as shown below.

In short-term studies, live fine-root abundance (or total fine-root abundance) increased with time, suggesting that over a period the rate of fine root production was continuously higher than the rate of mortality (or disappearance). Joslin and Wolfe (1999) showed that the installation of minirhizotron observa- tion tubes promotes fine-root production due to root pruning or increased nitrogen availability from fragmented root detritus in micro-sites near the tube, and also an altered vertical distribution pattern of fine roots. They found that fine-root production in the second and third years was lower than that in the first growing season (2-8 months after tube installation) at a nutrient-poor site. A 5-year study showed higher fine-root production in the first growing season after tube installation and higher mortality in the second growing season (Joslin et al., 2000). It was observed that many of the extra fine roots that had appeared in the first growing season were dead by the second year, which explains the higher fine-root mortality observed in the second growing season (Joslin et al., 2000). Furthermore, the fine roots at the soil-tube boundary in the first growing season were mostly new roots (Gill et al., 2002), leading to the lower fine-root mortality or decomposition observed in the first year. The difference between cumulative fine-root production and cumulative fine-root mortality decreased with time (Joslin et al., 2000), which could lead to results supporting the theoretical assumption of steady-state conditions (i.e. that the fine-root production turnover equals the fine-root mortality). Surprisingly, though, even in the fifth year after tube installation, the 5-year total fine-root production was slightly higher than the 5-year total fine-root mortality (Joslin et al., 2000), which suggests that several years are needed after tube installation for the fine root dynamics to attain equilibrium.

Inter-annual variation in climate could also influence fine-root production and mortality, allowing inter-annual fluctuations of the fine-root demographic parameters (Ruess et al., 1998). Thus, further long-term study is necessary to fully understand the carbon input-output balance through the fine-root PDD cycle.

\section{Implications of minirhizotron data validation}

Differences between the soil conditions around the observation tube and the bulk, in situ, soil conditions, such as water/nutrient movement and soil physiological traits, affect the fine-root standing biomass at the soil-tube interface, which means that the fine-root abundance calculated using the minirhizotron method is a relative value proportional to the actual biomass in bulk soil, as mentioned above. Calibration of the minirhizotron fine-root data against soil core sampling data is the first step in minirhizotron data validation (reviewed by Hendrick and Pregitzer, 1996), but in itself is insufficient for the study of fine-root dynamics (Milchunas et al., 2005; Hendricks et al., 2006). Soil conditions around the observation tube can affect the rates of fine-root production, mortality, and 
Table 2. Variously defined fine-root turnover values among soil depths in the literature calculated using the models shown in Fig. 1 with equations (1) to (12) in Table 1. Four types of fine-root turnover values are shown: production and mortality turnover calculated from the live fine-root abundance-based model (Fig. 1a) and production and disappearance turnover calculated from the visible fine-root (live + dead) abundance-based compartment model (Fig. 1b); means are given where possible. In the turnover calculations shown in Table 1, seven types of calculations are used, and four types of fine-root abundance data are used as denominators: mean and maximum values of each of live and visible fine-root abundance.

\begin{tabular}{|c|c|c|c|c|c|c|c|c|c|c|}
\hline \multirow{3}{*}{ Vegetation type $^{\mathrm{a}}$} & \multirow{3}{*}{ Dominant species } & \multirow{3}{*}{$\begin{array}{l}\text { Soil depth } \\
\quad(\mathrm{cm})\end{array}$} & \multirow{3}{*}{$\begin{array}{l}\text { Criterion to } \\
\text { define fine } \\
\text { root }\end{array}$} & \multicolumn{5}{|c|}{ Fine root turnover $\left(\right.$ year $\left.^{-1}\right)$} & \multirow{3}{*}{ Eq. ${ }^{c}$} & \multirow{3}{*}{ Reference } \\
\hline & & & & \multicolumn{2}{|c|}{ Live fine-root ${ }^{b}$ model } & \multicolumn{2}{|c|}{$\begin{array}{c}\text { Visible fine-root (live }+ \text { dead }{ }^{\mathrm{b}} \\
\text { model }\end{array}$} & \multirow{2}{*}{ Mean } & & \\
\hline & & & & Production & Mortality & Production & Disappearance & & & \\
\hline \multirow[t]{2}{*}{ Heathland } & Erica tetralix & $0-23$ & NA & 0.92 & & & & & 1 & Aerts et al. 1989 \\
\hline & Molina caerulea & $0-60$ & NA & 2.28 & & & & & 1 & \\
\hline \multirow[t]{5}{*}{ Shortgrass steppe } & Bouteloua gracilis & $0-20$ & $<2 \mathrm{~mm}$ & 0.83 & 0.30 & & & 0.57 & 3,6 & Gill et al. 2002 \\
\hline & & $20-40$ & $<2 \mathrm{~mm}$ & $*$ & * & & & & 3,6 & \\
\hline & & $40-60$ & $<2 \mathrm{~mm}$ & $*$ & $*$ & & & & 3,6 & \\
\hline & & $60-80$ & $<2 \mathrm{~mm}$ & $*$ & $*$ & & & & 3,6 & \\
\hline & & $80-100$ & $<2 \mathrm{~mm}$ & $*$ & $*$ & & & & 3,6 & \\
\hline \multirow[t]{6}{*}{ Shortgrass steppe } & Bouteloua gracilis, & $0-40$ & NA & & & 0.2125 & & & 9 & Milchunas et al. 2005 \\
\hline & Stipa comata and & $0-40$ & NA & & & 0.2102 & & & 9 & \\
\hline & Pascopyrum & $0-40$ & NA & & & 0.2119 & & & 9 & \\
\hline & & $0-40$ & NA & & & 0.4474 & & & 7 & \\
\hline & & $0-40$ & NA & & & 0.4801 & & & 7 & \\
\hline & & $0-40$ & NA & & & 0.4423 & & & 7 & \\
\hline \multirow[t]{2}{*}{ NLEF } & Pinus radiate & $0-31$ & NA & & 0.636 & & & & 4 & Pritchard et al. 2001 \\
\hline & & $0-31$ & NA & & 0.672 & & & & 4 & \\
\hline \multirow[t]{4}{*}{ BLDF } & Acer saccharum & $0-10$ & $<1 \mathrm{~mm}$ & 0.81 & 0.52 & & & 0.66 & 1,4 & Burton et al. 2000 \\
\hline & (Site A) & $20-30$ & $<1 \mathrm{~mm}$ & 0.88 & 0.48 & & & 0.68 & 1,4 & \\
\hline & & $40-50$ & $<1 \mathrm{~mm}$ & 1.06 & 0.20 & & & 0.63 & 1,4 & \\
\hline & & $0-50$ & $<1 \mathrm{~mm}$ & 0.83 & 0.50 & & & 0.66 & 1,4 & \\
\hline
\end{tabular}


Continued from previous page

\begin{tabular}{|c|c|c|c|c|c|c|c|c|c|c|}
\hline \multirow{3}{*}{ Vegetation type $^{a}$} & \multirow{3}{*}{ Dominant species } & \multirow{3}{*}{$\begin{array}{l}\text { Soil depth } \\
\text { (cm) }\end{array}$} & \multirow{3}{*}{$\begin{array}{c}\text { Criterion to } \\
\text { define fine } \\
\text { root }\end{array}$} & \multicolumn{5}{|c|}{ Fine root turnover $\left(\right.$ year $\left.^{-1}\right)$} & \multirow{3}{*}{ Eq. ${ }^{c}$} & \multirow{3}{*}{ Reference } \\
\hline & & & & \multicolumn{2}{|c|}{ Live fine-root ${ }^{\mathrm{b}}$ model } & \multicolumn{2}{|c|}{$\begin{array}{c}\begin{array}{l}\text { Visible fine-root (live }+ \text { dead })^{\mathrm{b}} \\
\text { model }\end{array} \\
\end{array}$} & \multirow{2}{*}{ Mean } & & \\
\hline & & & & Production & Mortality & Production & Disappearance & & & \\
\hline \multirow[t]{4}{*}{ BLDF } & \multirow{4}{*}{$\begin{array}{l}\text { Acer saccharum } \\
\quad \text { (Site B) }\end{array}$} & $0-10$ & $<1 \mathrm{~mm}$ & 0.76 & 0.42 & & & 0.59 & 1,4 & Burton et al. 2000 \\
\hline & & $20-30$ & $<1 \mathrm{~mm}$ & 0.76 & 0.25 & & & 0.50 & 1,4 & \\
\hline & & $40-50$ & $<1 \mathrm{~mm}$ & 0.81 & 0.25 & & & 0.53 & 1,4 & \\
\hline & & $0-50$ & $<1 \mathrm{~mm}$ & 0.76 & 0.36 & & & 0.56 & 1,4 & \\
\hline \multirow{4}{*}{ BLDF } & \multirow{4}{*}{$\begin{array}{l}\text { Acer saccharum } \\
\quad(\text { Site } \mathrm{C})\end{array}$} & $0-10$ & $<1 \mathrm{~mm}$ & 0.72 & 0.36 & & & 0.54 & 1,4 & Burton et al. 2000 \\
\hline & & $20-30$ & $<1 \mathrm{~mm}$ & 0.77 & 0.39 & & & 0.58 & 1,4 & \\
\hline & & $40-50$ & $<1 \mathrm{~mm}$ & 0.89 & 0.48 & & & 0.68 & 1,4 & \\
\hline & & $0-50$ & $<1 \mathrm{~mm}$ & 0.75 & 0.37 & & & 0.56 & 1,4 & \\
\hline \multirow[t]{4}{*}{ BLDF } & \multirow{4}{*}{$\begin{array}{l}\text { Acer saccharum } \\
\quad \text { (Site D) }\end{array}$} & $0-10$ & $<1 \mathrm{~mm}$ & 0.82 & 0.52 & & & 0.67 & 1,4 & Burton et al. 2000 \\
\hline & & $20-30$ & $<1 \mathrm{~mm}$ & 0.76 & 0.50 & & & 0.63 & 1,4 & \\
\hline & & $40-50$ & $<1 \mathrm{~mm}$ & 0.85 & 0.50 & & & 0.68 & 1,4 & \\
\hline & & $0-50$ & $<1 \mathrm{~mm}$ & 0.80 & 0.50 & & & 0.65 & 1,4 & \\
\hline \multirow[t]{5}{*}{ BLDF } & \multirow{5}{*}{$\begin{array}{l}\text { Quercus crispula, } \\
\text { Betula ermanii, } \\
\text { Betula platyphylla }\end{array}$} & $0-5$ & $<1 \mathrm{~mm}$ & & & 1.10 & 1.14 & 1.12 & 9,12 & Satomura et al. 2006 \\
\hline & & $5-10$ & $<1 \mathrm{~mm}$ & & & 1.19 & 0.73 & 0.96 & 9,12 & \\
\hline & & $10-15$ & $<1 \mathrm{~mm}$ & & & 1.22 & 0.48 & 0.85 & 9,12 & \\
\hline & & $15-20$ & $<1 \mathrm{~mm}$ & & & 0.94 & 0.35 & 0.65 & 9,12 & \\
\hline & & $0-20$ & $<1 \mathrm{~mm}$ & & & 1.11 & & & 9 & \\
\hline \multirow[t]{3}{*}{ BLDF } & \multirow[t]{3}{*}{ Quercus crispula } & $0-15$ & $<2 \mathrm{~mm}$ & & & 1.7 & 1.0 & 1.4 & 9,12 & Fukuzawa et al. 2007 \\
\hline & & $15-30$ & $<2 \mathrm{~mm}$ & & & 1.0 & 0.2 & 0.6 & 9,12 & \\
\hline & & $30-45$ & $<2 \mathrm{~mm}$ & & & 0.8 & 0.0 & 0.4 & 9,12 & \\
\hline
\end{tabular}

${ }^{a}$ BLDF, broad-leaved deciduous forest; NLEF, needle-leaved evergreen forest.

${ }^{\mathrm{b}}$ Live fine-root abundance and visible fine-root (live + dead) abundance are expressed variously as root length per tube, root length per image or root length per unit observation area.

${ }^{\mathrm{c}}$ Equations shown in Table 1.

-, No definition for dead roots; NA, data not available; *, data are presented in a figure in the original literature, but the values are not stated in the text. 
disappearance, as revealed by a comparison of the effects of tube materials on fine-root dynamics and characteristics (Withington et al., 2003). Not only fine-root abundance data but also fine-root demographic data produced by the minirhizotron method are relative values with respect to the bulk, in situ condition.

To validate estimates of fine-root production and mortality rate using minirhizotrons, Hendrick et al. used a minirhizotron data validation index utilizing equations (15) and (16) to show the difference between predicted and actual final standing biomass as follows:

$\mathrm{D}=A \times(B / C)$

where $\mathrm{D}$ is the predicted final standing biomass $(\mathrm{kg}$ $\left.\mathrm{ha}^{-1}\right), A$ is the initial standing biomass $\left(\mathrm{kg} \mathrm{ha}^{-1}\right)$ obtained using the soil core sampling method, $B$ is the minirhizotron production estimate $\left(\mathrm{mm} \mathrm{cm}^{-2} \mathrm{day}^{-1}\right)$, and $C$ is the minirhizotron mortality estimate $(\mathrm{mm}$ $\mathrm{cm}^{-2} \mathrm{day}^{-1}$ ). The minirhizotron data validation index can therefore be defined as the percentage difference between the actual and predicted final standing biomass:

minirhizotron data validation index

$$
=((E-D) / E) \times 100
$$

where $E$ is the actual final standing biomass $\left(\mathrm{kg} \mathrm{ha}^{-1}\right)$ obtained using the soil core sampling method (Hendrick and Pregitzer,1993; Hendricks et al., 2006).

This index gives the degree of difference between predicted and actual fine-root standing biomass. In the results of Hendricks et al. (2006), absolute values of their index were greatest after the first sample interval (just after tube setting) at three sites $(>198)$, but decreased significantly and more or less stabilized after subsequent sample intervals (i.e. after presumed equilibration) (2.8-24.3). Furthermore, after stabilization, the predicted fine-root standing biomass values were within one standard deviation of the actual values at each site. Thus, the minirhizotron data validation index is useful for minirhizotron data validation and allows evaluation of the equilibrium of fine-root dynamics at the soil-tube interface after tube installation disturbance.

Each plant species has a certain balance between leaf production and fine-root production which can be expressed as a ratio, or as a proportion of fine root production to total fine tissue (fine-root and leaf) production, with some plasticity. Withington et al. (2003) proposed such a fine-root vs. leaf balance as another index for assessment of the effect of different soil conditions around observation tubes. The fine-root vs. leaf balance differs among the varying methods used to study fine-root production (reviewed by Hendricks et al., 2006) or among tube materials in the minirhizotron method (Withington et al., 2003). However, the use of a single tube material with a single calculation method in a minirhizotron fine-root production study produced similar fine-root to leaf production ratios in forests dominated by Acer saccharum (180\% and 191\%; Hendrick and Pregitzer, 1993), which does not conflict with the supposition mentioned above. The fine-root to leaf production ratio also showed similar values in two of three Pinus palustris stands $(71 \%$ in a hydric stand and $66 \%$ in a xeric stand), but a relatively low value (32\%) in the third stand, which was mesic (Hendricks et al., 2006). Although the mesic stand had a similar fine-root production rate to the hydric stand, it was characterized by a lower initial fine-root biomass than the others, which gave a lower fine-root production estimate, and thus a lower fine-root to leaf production ratio. Apart from this exception, in a comparison of fine-root dynamics among forests dominated by a certain tree species and using a single tube material with a single calculation approach in the minirhizotron method, the fine-root vs. leaf balance method seems to be a good indicator for the validation of minirhizotron data.

\section{Variation in turnover values among "fine roots"}

\section{Variation with soil depth}

Soil conditions and environmental parameters are not uniform among soil depths (Nagatsuka, 1997; Fisher and Binkley, 2000). Soil temperature, water and nutrient availabilities and microbial biomass frequently decrease with depth (Ajwa et al., 1998; Uchida et al., 1998; Fierer et al., 2003; Fujimaki et al., 2004), leading to lower fine-root production and mortality rates (or disappearance rates) in deeper soil (e.g. Aerts et al., 1989; Milchunas et al., 2005; Fukuzawa et al., 2007). In contrast, severely arid soil conditions can reduce root production and mortality rates in shallower depths, according to root biomass distribution patterns, due to the restriction of water and nutrient availabilities at the surface (Rundel and Nobel, 1991). Although there is a growing number of reports detailing fine-root production and mortality rates (or disappearance rates) with soil depth, the data for fine-root turnover values with soil depth are restricted, and we can only find a few studies, as shown in Table 2 (in one study, data are present in a figure, but the values are not stated in the text; West et al., 2004).

In one of these studies, Gill et al. (2002) found that production turnover was higher than mortality turnover at various soil depths in steppe grassland. Both 
rates of fine-root production and mortality decreased with soil depths. Although they had hypothesized that root turnover would decrease with soil depth, in fact the effect was not significant. In a needle-leaved evergreen forest dominated by Pinus palustris and Aristida stricta, fine-root production turnover and fine-root mortality turnover as well as fine-root production and mortality rates decreased with soil depth (West et al. 2004). In Acer saccharum forests, where both fine-root production rate and mortality rate decreased with depth, fine-root production turnover mainly decreased with soil depth, whereas fine-root mortality turnover mainly increased with soil depth (Burton et al., 2000; Table 2).

The relationships between fine-root production rate and production turnover values, between fine-root mortality rate and mortality turnover values, and between fine-root disappearance rate and disappearance turnover values are uncertain. We have attempted to analyze those relations by comparing data collected in similar types of forest with different overstory tree densities.

In cool-temperate deciduous forests (dominated by Quercus crispula with a dense understory of Sasa senanensis), we found that with increasing soil depth, the fine-root production rate and the fine-root disappearance rate decreased (Satomura et al., 2006; Fukuzawa et al., 2007), as did fine-root disappearance turnover (Table 2). Fine-root disappearance turnover incorporates the fine-root decomposition process and the fine-root mortality process. Generally, a lower decomposition rate is expected in the deeper soil than at the soil surface, because of less conducive decomposition promoting parameters, such as soil temperature and microbial biomass (Ajwa et al., 1998; Uchida et al., 1998; Fierer et al., 2003). Our findings do not conflict with the expectation of a lower decomposition rate in the deeper soil. Furthermore, in some cases fine-root longevity has been shown to be greater in deeper soil than at the soil surface (Arnone et al., 2000; Anderson et al., 2003), which is also compatible with our results. Subdividing fine roots into several categories according to micro-size root diameter revealed that fine roots in the deeper soil tended to be coarser than at the soil surface, and coarser 'fine roots' tended to have longer life spans (Anderson et al., 2003), suggesting that qualitative variations within fine roots (see below for related material) could also be closely related to the variation in fine-root turnover among soil depths.

The patterns of fine-root production turnover at different soil depths varied between forests, even though they were all cool-temperate deciduous forests. In one forest in northern Japan, production turnover decreased with depth (Fukuzawa et al., 2007; Table 2), but in a central Japanese forest, fine-root production turnover was very similar at different soil depths (Satomura, 2003; Satomura et al., 2006; Table 2). It is hard to compare the two studies because the soil depths were different between the two sites and the effects of the varying soil conditions with depth on fine-root demography remain uncertain. However, the different fine-root production turnover patterns among soil depths between these forests could also be partly due to the difference in tree density (sparse in the former, dense in the latter).

\section{Qualitative variation among "fine roots"}

As mentioned above, the term 'fine root' has been defined variously depending on the site, target tree species, or researchers' conventions (Majdi et al., 2005). Most researchers use a diameter of 2 or $1 \mathrm{~mm}$ as the threshold value (reviewed by Vogt et al., 1996; Gill and Jackson, 2000). Gill and Jackson (2000) reviewed the root turnover data (for all definitions) collected from all kinds of methods and summarized the fine-root turnover data into 6 diameter classes. In general, fine-root turnover increases with a decreasing size threshold for the definition of a 'fine root' (Gill and Jackson, 2000). Therefore, we must pay attention to the definitions of fine roots when we compare recorded turnover values with values in the literature.

Recent studies have revealed significant variation in form and function of fine roots $\leq 2 \mathrm{~mm}$ in diameter (e.g. Pregitzer et al., 2002; Trumbore and Gaudinski, 2003; Guo et al., 2004). Generally, fine roots live for a few months on average, but some fine roots can live remarkably longer, i.e. several years or more (Tierney and Fahey, 2002; Trumbore and Gaudinski, 2003). Survival in the population of fine roots $(\leq 0.5 \mathrm{~mm}$ in diameter) decreased according to a lognormal rather than an exponential model, and thus the rate of fine-root mortality changes with root age (Tierney and Fahey, 2002; Wells et al., 2002). It is also known that the season (or time) of emergence can alter fine-root life span (e.g. Tingey et al., 2000; Ponti et al., 2004; Table 1), as can tree age (Copeland, 1952; Baddeley and Watson, 2005). The categorization according to micro-size root diameter revealed that thinner fine roots tended to have shorter life spans than thicker fine roots (Wells and Eissenstat, 2001; Baddeley and Watson, 2005). The diameter of 'fine roots' can also differ along root branching orders: roots with an apex (root tip) are thinner than the axis roots to which they are attached (Pregitzer et al., 2002; Guo et al., 2004), suggesting shorter life spans in thinner apical roots. Further, in addition to carbon-fraction concentrations, such as cellulose and lignin, the $\mathrm{C} / \mathrm{N}$ ratio can also differ among root branching orders (Pregitzer et al., 2002; Guo et al., 2004; Hishi and Takeda, 2005b), suggesting that roots in different branching orders 
have different decomposition rates.

It was clarified recently by Hishi and Takeda $(2005 \mathrm{a}, \mathrm{b})$ that fine-root architecture and anatomical traits (i.e. branching position and tissue structure) are closely related to fine-root life span. In that study they subdivided Chamaecyparis obtusa fine roots into four protoxylem groups (diarch through pentarch) and studied their production. The results suggested that fine roots with less protoxylem had shorter life spans, and those with more protoxylem had longer life spans and greater opportunities for secondary growth and ramification.

In general, fine-root architecture is closely related to ectomycorrhizal associations (e.g. Chilvers and Gust, 1982a; Agerer, 1999; Majdi et al., 2001), suggesting that the fine-root mycorrhizal status could also be related to fine-root demography. The fine-root growth rate was the highest in tap roots (first-order roots) and decreased with root order in both ectomycorrhizal and non-mycorrhizal roots (Chilvers and Gust, 1982b). In addition, under a similar (but not the same) root order concept, higher-order ectomycorrhizal fine roots had greater longevity than lower-order ectomycorrhizal fine roots (Majdi et al., 2001). The higher-order fine roots tended to have dense ectomycorrhizal association, whereas lower-order fine roots tended to have sparse ectomycorrhizal association, resulting in a lower fine-root growth rate in ectomycorrhizal than in non-mycorrhizal fine roots (Chilvers and Gust, 1982b). Even when the same-order roots were compared between ectomycorrhizal and non-mycorrhizal roots, the fine-root growth rate in ectomycorrhizal fine roots was lower than that in non-mycorrhizal fine roots (Chilvers and Gust, 1982b). Another report also showed that ectomycorrhizal fine roots had longer life spans and smaller turnover than non-mycorrhizal fine roots (King et al., 2002).

\section{Conclusion}

Various methods have been used for the study of fine root production. With all methods, the estimate of fine-root production is less accurate than that obtained for other parameters related to forest carbon cycling, which can be attributed to the spatiotemporal variation of fine-root distribution and the qualitative variation of the fine roots. However, for the study of fine-root production, mortality and dynamics, the minirhizotron method is recommended, and the data taken by this method is considered to have higher reliability than the other methods (Hendricks et al., 2006; Majdi et al., 2005).

When we compare fine-root turnover values estimated by the minirhizotron method, we must pay attention to the definition of fine roots, methods of measuring, and methods of calculation, all of which affect fine-root turnover estimates. Many short-term studies have revealed that net root production is greater than net root mortality (or disappearance), which seems to conflict with the steady-state theory of root turnover, which states that net root production and net root mortality are the same. The effect of soil disturbance by minirhizotron installation could partially account for this contradiction and long-term research into fine-root dynamics and the effects of biotic and abiotic factors at different soil depths would help resolve this. Even though soil disturbance affects estimates of fine-root turnover in short-term research, the estimated turnover values from short-term studies give the maximum limit of the turnover, which can be expressed as dry matter transfer (or carbon transfer) through the fine-root PDD cycle for different types of forest, and thereby provide better knowledge of forest carbon dynamics. The minirhizotron data validation procedure makes those estimates more reliable.

Recent studies have revealed variations in fine-root turnover values with soil depth. 'Fine root' qualitative variations, such as anatomical characteristics, architecture, mycorrhizal abundance, and age, could also affect turnover values. The relation between biotic or abiotic parameters that potentially affect fine-root dynamics and the qualitative variations among 'fine roots' and their interactive effect on 'fine-root' turnover estimates are unclear. Although there could be many problems, a better understanding of 'fine roots' would lead to more accurate estimates of fine-root turnover, and finally, root sampling based on form and function would give us better knowledge of root dynamics and demography.

\section{Acknowledgements}

We wrote this review following discussions on root research using minirhizotrons in a seminar at the National Institute for Environmental Studies. We are grateful to Dr. Yasumi Fujinuma and Dr. Tatsuro Nakaji for inviting us the seminar. Unknown reviewers and Dr. A. Kume of Toyama University made helpful comments and suggestions. This study was conducted as part of the "Carbon Cycle and Larch Growth (CC-LaG) Experiment" in the Teshio Experimental Forest of Hokkaido University. It was partly supported by the Grants for the JSPS 21st Century COE Program "Satellite Ecology" of Gifu University and by the JSPS 21st Century COE Program "Biodiversity Research" (A2) of Kyoto University, and a Grant-in-Aid from the Japan Society for the Promotion of Science, No. 16570018.

\section{References}

Aerts R, Berendse F, Klerk NM, Bakker C 1989 Root produc- 
tion and root turnover in two dominant species of wet heathlands. Oecologia 81: 374-378.

Agerer R 1999 Anatomical characteristics of identified ectomycorrhizas: An attempt towards a natural classification. In: Varma A, Hock B, Eds., Mycorrhiza, Second Edition. Springer-Verlagm Berlin Heidelberg, pp. 633-682.

Ajwa HA, Rice CW, Sotomayor D 1998 Carbon and nitrogen mineralization in tallgrass prairie and agricultural soil profiles. Soil Sci. Soc. Am. J. 62: 942-951.

Anderson LJ, Comas LH, Lakso AN, Eissenstat DM 2003 Multiple risk factors in root survivorship: a 4-year study in Concord grape. New Phytol. 158: 489-501.

Arnone AJ III, Zaller JG, Spehn EM, Niklaus PA, Wells CE, Körner C 2000 Dynamics of root systems in native grasslands: effects of elevated atmospheric $\mathrm{CO}_{2}$. New Phytol. 147: 73-85.

Baddeley JA, Watson CA 2005 Influences of root diameter, tree age, soil depth and season on fine root survivorship in Prunus avium. Plant Soil 276: 15-22.

Burton AJ, Pregitzer KS, Hendrick RL 2000 Relationships between fine root dynamics and nitrogen availability in Michigan northern hardwood forests. Oecologia 125: 389-399.

Chilvers GA, Gust LW 1982a The development of mycorrhizal populations on pot-grown seedlings of Eucalyptus st-johnii R. T. Bak. New Phytol. 90: 677-699.

Chilvers GA, Gust LW 1982b Comparisons between the growth rates of mycorrhizas, uninfected roots and a mycorrhizal fungus of Eucalyptus st-johnii R. T. Bak. New Phytol. 91: 453-466.

Comeau PG, Kimmins JP 1989 Above- and below-ground biomass and production of lodgepole pine on sites with different soil moisture regimes. Can. J. For. Res. 19: 447-454.

Copeland OL 1952 Root mortality of shortleaf and loblolly pine in relation to soils and littleleaf disease. J. For. 50: 21-25.

Eissenstat DM 1992 Costs and benefits of constructing roots of small diameter. J. Plant Nutr. 15: 763-782.

Ephrath JE, Silberbush M, Berliner PR 1999 Calibration of minirhizotron readings against root length density data obtained from soil cores. Plant Soil 209: 201-208.

Fahey TJ, Bledsoe CS, Day FP, Ruess RW, Smuker AJM 1999 Fine root production and demography. In: Robertson GP, Coleman DC, Bledsoe CS, Sollins P, Eds., Standard Soil Methods for Long-Term Ecological Research. Oxford University Press, Oxford, pp. 437-455.

Fierer N, Allen AS, Schimel JP, Holden PA 2003 Controls on microbial $\mathrm{CO}_{2}$ production: a comparison of surface and subsurface soil horizons. Global Change Biol. 9: 1322-1332.

Fisher RF, Binkley D 2000 Ecology and Management of Forest Soils, Third Edition. Wiley, New York, 489 pp.

Fujimaki R, Tateno R, Hirobe M, Tokuchi N, Takeda H 2004 Fine root mass in relation to soil $\mathrm{N}$ supply in a cool temperate forest. Ecol. Res. 19: 559-562.

Fukuzawa K 2007 The role of fine roots in carbon and nitrogen dynamics in a cool-temperate forest covered with Sasa dwarf bamboo. Doctoral Thesis. Graduate School of Agriculture, Hokkaido University, Sapporo, Japan, pp. 1-104. (in Japanese)

Fukuzawa K, Shibata H, Takagi K, Satoh F, Koike T, Sasa K 2007 Vertical distribution and seasonal pattern of fine-root dynamics in a cool-temperate forest in northern Japan: implication of the understory vegetation, Sasa dwarf bamboo. Ecol. Res. (in press, DOI: 10.1007/s11284-006-0031-y)
Gholz HL, Hendry LC, Cropper WP Jr. 1986 Organic matter dynamics of fine roots in plantations of slash pine (Pinus elliottii) in north Florida. Can. J For. Res. 16: 529-538.

Gill RA, Jackson RB 2000 Global patterns of root turnover for terrestrial ecosystems. New Phytol. 147: 13-31.

Gill RA, Burke IC, Lauenroth WK, Milchunas DG 2002 Longevity and turnover of roots in the shortgrass steppe: influence of diameter and depth. Plant Ecol. 159: 241-251.

Guo DL, Mitchell RJ, Hendricks JJ 2004 Fine root branch orders respond differentially to carbon source-sink manipulations in a longleaf pine forest. Oecologia 140: 450-457.

Hendrick RL, Pregitzer KS 1992 The demography of fine roots in a northern hardwood forest. Ecology 73: 1094-1104.

Hendrick RL, Pregitzer KS 1993 The dynamics of fine root length, biomass, and nitrogen content in two northern hardwood ecosystems. Can. J. For. Res. 23: 2507-2520.

Hendrick RL, Pregitzer KS 1996 Applications of minirhizotrons to understand root function in forests and other ecosystems. Plant Soil 185: 293-304.

Hendricks JJ, Hendrick RL, Wilson CA, Mitchell RJ, Pecot SD, Fuo D 2006 Assessing the patterns and controls of fine root dynamics: an empirical test and methodological review. J. Ecol. 94: 40-57.

Hishi T, Takeda H 2005a Life cycles of individual roots in fine root systems of Chamaecyparis obtusa Sieb. et Zucc. J. For. Res. 10: 181-187.

Hishi T, Takeda H 2005b Dynamics of heterorhizic root systems: protoxylem groups within the fine-root systems of Chamaecyparis obtusa. New Phytol. 167: 509-521.

Hynes BE, Gower ST 1995 Belowground carbon allocation in unfertilised and fertilised red pine plantations in northern Wisconsin. Tree Physiol. 15: 317-325.

Janssens IA, Sampson DA, Curiel-Yuste J, Carrara A, Ceulemans R 2002 The carbon cost of fine root turnover in a Scots pine forest. For. Ecol. Manag. 168: 231-240.

Johnson MG, Tingey DT, Phillips DL, Storm MJ 2001 Advancing fine root research with minirhizotrons. Environ. Exp. Bot. 45: 263-289.

Joslin JD, Wolfe MH 1999 Disturbances during minirhizotron installation can affect root observation data. Soil Sci. Soc. Am. J. 63: 218-221.

Joslin JD, Wolfe MH, Hanson PJ 2000 Effects of altered water regimes on forest root systems. New Phytol. 147: 117-129.

Keyes MR, Grier CC 1981 Above- and below-ground net production in 40-year-old Douglas-fir stands on low and high productivity sites. Can. J. For. Res. 11: 599-605.

King JS, Albaugh TJ, Allen HL, Buford M, Strain BR, Dougherty P 2002 Below-ground carbon input to soil is controlled by nutrient availability and fine root dynamics in loblolly pine. New Phytol. 154: 389-398.

Kurz WA and Kimmins JP 1987 Analysis of some sources of error in methods used to determine fine root production in forest ecosystems: a simulation approach. Can. J. For. Res. 17: 909-912.

Majdi H 1996 Root sampling methods - applications and limitations of the minirhizotron technique. Plant Soil 185: 255-258.

Majdi H, Damm E, Nylund J-E 2001 Longevity of mycorrhizal roots depends on branching order and nutrient availability. New Phytol. 150: 195-202.

Majdi H, Pregitzer K, Morén, A-S, Nylund J-E, Ågren GI 2005 Measuring fine root turnover in forest ecosystems. Plant Soil 276: 1-8.

Milchunas DG, Morgan JA, Mosier AR, Lecain DR 2005 Root dynamics and demography in shortgrass steppe under 
elevated $\mathrm{CO}_{2}$, and comments on minirhizotron methodology. Global Change Biol. 11: 1837-1855.

Nagatsuka S 1997 Ecological Atlas of Soils in Japan. Fuji Technosystem, Tokyo, 218 pp. (in Japanese)

Noguchi K, Sakata T, Mizoguchi T, Takahashi M 2004 Estimation of fine root biomass in Japanese ceder (Cryptomeria japonica D. Don) plantation using a minirhizotrons. J. For. Res. 9: 261-264.

Noguchi K, Sakata T, Mizoguchi T, Takahashi M 2005 Estimating the production and mortality of fine roots in a Japanese cedar (Cryptomeria japonica D. Don) plantation using a minirhizotron technique. J. For. Res. 10: 435-441.

Ponti F, Minotta G, Cantoni L, Bagnaresi U 2004 Fine root dynamics of pedunculate oak and narrow-leaved ash in a mixed-hardwood plantation in clay soils. Plant Soil 259: $39-49$.

Pregitzer KS, Laskowski MI, Burton AJ, Lessard VC, Zak DR 1998 Variation in sugar maple root respiration with root diameter and soil depth. Tree Physiol. 18: 665-670.

Pregitzer KS, De Forest JL, Burton AJ, Allen MF, Ruess RW, Henricks RL 2002 Fine root architecture of nine north American trees. Ecological Monographs 72: 293-309.

Pritchard SG, Rogers HH, Davis MA, Van Santen E, Prior SA, Schlesinger WH 2001 The influence of elevated atmospheric $\mathrm{CO}_{2}$ on fine root dynamics in an intact temperate forest. Global Change Biol. 7: 829-837.

Publicover DA, Vogt KA 1993 A comparison of methods for estimating forest fine root production with respect to sources of error. Can. J. For. Res. 23: 1179-1186.

Ruess RW, Hendrick RL, Bryant JP 1998 Regulation of fine root dynamics by mammalian browsers in early successional Alaskan taiga forests. Ecology 79: 2706-2720.

Rundel PW, Nobel PS 1991 Structure and function in desert root systems. In: Atkinson D, Ed., Plant Root Growth. Blackwell Scientific Publications, Oxford, pp.349-378.

Stanton NL 1988 The underground in grasslands. Annu. Rev. Ecol. Syst. 19: 573-589.

Satomura T 2003 Biomass of fine roots and mycorrhizal fungi in forest ecosystems. Doctoral Thesis. Graduate School of Biosphere Science, Hiroshima University, Higashi-Hiroshima, Japan, pp. 1-150. (in Japanese with English abstract)

Satomura T, Nakane K, Horikoshi T 2001 Analysis of fine root net primary productivity of trees using minirhizotron method. Root Res. 10: 3-12. (in Japanese)

Satomura T, Hashimoto Y, Koizumi H, Nakane K, Horikoshi T 2006 Seasonal patterns of fine root demography in a cool-temperate deciduous forest in central Japan. Ecol. Res. 21: 741-753.

Smit AL, George E, Groenwold J 2000 Root observations and measurements at (transparent) interfaces with soil. In: Smit AL, Bengough AG, Engels C, van Noordwijk M, Pellerin S, van de Geijn SC, Eds., Root Methods: A Hand Book. Springer, Berlin, pp. 235-271.

Taylor HM 1987 Minirhizotorn observation tubes: Methods and applications for measuring rhizosphere dynamics. ASA Special Publication Number 50. American Society of Agronomy, Inc., Crop Science Society of America, Inc., Soil Science Society of America, Inc., Madison, WI, USA, pp. 1-143.

Thomas SM, Whitehead D, Adams JA, Reid JB, Sherlock RR, Leckie AC 1996 Seasonal root distribution and soil surface carbon fluxes for one-year-old Pinus radiata trees growing at ambient and elevated carbon dioxide concentration. Tree Physiol. 16: 1015-1021.

Tierney GL, Fahey TJ 2001 Evaluating minirhizotron estimates of fine root longevity and production in the forest floor in a temperate broadleaf forest. Plant Soil 299: 167-176.

Tierney GL, Fahey TJ 2002 Fine root turnover in northern hardwood forest: a direct comparison of the radiocarbon and minirhizotron methods. Can. J. For. Res. 32: 1692-1697.

Tierney GL, Fahey TJ, Groffman PM, Hardy JP, Fitzhugh RD, Driscoll CT, Yavitt JB 2003 Environmental control of fine root dynamics in a northern hardwood forest. Global Change Biol. 9: 670-679.

Tingey DT, Phillips DL, Johnson MG 2000 Elevated $\mathrm{CO}_{2}$ and conifer roots: effects on growth, life span and turnover. New Phytol. 147: 87-103.

Trumbore SE, Gaudinski JB 2003 The secret lives of roots. Science 302: 1344-1345.

Uchida M, Nakatsubo T, Horikoshi T, Kanake K 1998 Contribution of micro-organisms to the carbon dynamics in black spruce (Picea mariana) forest soil in Canada. Ecol. Res. 13: 17-26.

Vogt KA, Grier CC, Meier CA, Edmonds RL 1982 Mycorrhizal role in net primary production and nutrient cycling in Abies amabilis ecosystems in western Washington. Ecology 63: 370-380.

Vogt KA, Vogt DJ, Palmiotto PA, Boon P, O'Hara J, Asbornsen H 1996 Review of root dynamics in forest ecosystems grouped by climate, climatic forest type and species. Plant Soil 187: 159-219.

Vogt KA, Vogt DJ, Bloomfield J 1998 Analysis of some direct and indirect methods for estimating root biomass and production of forests at an ecosystem level. Plant Soil 200: 71-89.

Wells CE, Eissenstat DM 2001 Marked differences in survivorship among apple roots of different diameters. Ecology 82: 882-893.

Wells CE, Glenn DM, Eissenstat DM 2002 Changes in the risk of fine-root mortality with age: a case study in peach, Prunus persica (Rosaceae). Am. J. Bot. 89: 79-87.

West JB, Espeleta JF, Donovan LA 2004 Fine root production and turnover across a complex edaphic gradient of a Pinus palustris-Aristida stricta savanna ecosystem. For. Ecol. Manag. 189: 397-406.

Withington JM, Elkin AD, Bułaj B, Olesiński J, Tracy KN, Bouma TJ, Oleksyn J, Anderson LJ, Modrzyński J, Reich PB, Eissenstat DM 2003 The impact of material used for minirhizotron tubes for root research. New Phytol. 160: 533-544.

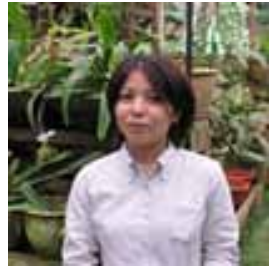

Dr. Takami Satomura's research interests are global warming and biogeochemical cycling, especially the role of fine roots and mycorrhizal fungi in forest carbon cycling.

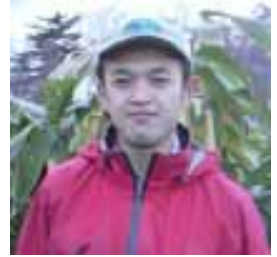

Dr. Karibu Fukuzawa's research interests are carbon and nitrogen cycling in forest ecosystems, especially fine root turnover and soil-stream chemistry. 